\title{
Antiviral Efficacy of Ribavirin and Favipiravir against Hantaan Virus
}

\author{
Jennifer Mayor ${ }^{1,2}$, Olivier Engler ${ }^{2} \mathbb{D}$ and Sylvia Rothenberger 1,2,* \\ 1 Institute of Microbiology, University Hospital Center and University of Lausanne, \\ CH-1011 Lausanne, Switzerland; jennifer.mayor@unil.ch \\ 2 Spiez Laboratory, Federal Office for Civil Protection, CH-3700 Spiez, Switzerland; \\ Olivier.Engler@babs.admin.ch \\ * Correspondence: Sylvia.Rothenberger-Aubert@chuv.ch; Tel.: +41-213145103
}

Citation: Mayor, J.; Engler, O.; Rothenberger, S. Antiviral Efficacy of Ribavirin and Favipiravir against Hantaan Virus. Microorganisms 2021, 9, 1306. https://doi.org/10.3390/ microorganisms 9061306

Academic Editor: Valeria Cagno

Received: 14 May 2021

Accepted: 15 June 2021

Published: 15 June 2021

Publisher's Note: MDPI stays neutral with regard to jurisdictional claims in published maps and institutional affiliations.

Copyright: (c) 2021 by the authors. Licensee MDPI, Basel, Switzerland. This article is an open access article distributed under the terms and conditions of the Creative Commons Attribution (CC BY) license (https:// creativecommons.org/licenses/by/ $4.0 /)$.

\begin{abstract}
Ecological changes, population movements and increasing urbanization promote the expansion of hantaviruses, placing humans at high risk of virus transmission and consequent diseases. The currently limited therapeutic options make the development of antiviral strategies an urgent need. Ribavirin is the only antiviral used currently to treat hemorrhagic fever with renal syndrome (HFRS) caused by Hantaan virus (HTNV), even though severe side effects are associated with this drug. We therefore investigated the antiviral activity of favipiravir, a new antiviral agent against RNA viruses. Both ribavirin and favipiravir demonstrated similar potent antiviral activity on HTNV infection. When combined, the efficacy of ribavirin is enhanced through the addition of low dose favipiravir, highlighting the possibility to provide better treatment than is currently available.
\end{abstract}

Keywords: Hantaan virus; ribavirin; favipiravir; combination therapy

\section{Introduction}

Orthohantaviruses (hereafter referred to as hantaviruses) are emerging negativestrand RNA viruses associated with two life-threatening diseases: hemorrhagic fever with renal syndrome (HFRS) and hantavirus cardiopulmonary syndrome (HCPS). Old World hantaviruses, including the prototypic Hantaan virus (HTNV) and Seoul virus (SEOV) are widespread in Asia where they can cause HFRS with up to $15 \%$ case-fatality. The New World hantaviruses Sin Nombre (SNV) and Andes (ANDV) are associated with HCPS in the Americas with up to $40 \%$ mortality. In Europe, Puumala virus (PUUV) causes nephropathia epidemica (NE), a milder form of HFRS, while Dobrava-Belgrade virus (DOBV) in the Balkans is associated with the more severe form of HFRS [1,2]. Rodents and insectivores represent the natural reservoir of hantaviruses, in which infections are persistent but asymptomatic. Humans' infection is mainly transmitted by direct inhalation of contaminated rodent excreta [2,3], while human-to-human transmission has also been reported for ANDV via close contact with symptomatic persons [4-7].

Although a vaccine is available in several Asian countries (Hantavax ${ }^{\circledR}$ ), the therapeutic options in Europe or the U.S.A. are limited to supportive care [8,9]. The only established antiviral drug with some efficacy in vitro and in vivo against hantaviruses is the nucleoside analogue ribavirin, approved in 1986, with broad-spectrum antiviral activity [10-12]. Ribavirin has some beneficial effects on HFRS patients, whereas treatment of HCPS with this drug remains inconclusive [1,13,14]. Moreover, the use of ribavirin is associated with side effects, including hemolytic anemia, and the drug cannot be applied in pregnant women. More effective antiviral therapies are therefore needed. A promising candidate that could be used in the future for hantavirus treatment is favipiravir, also known as T-705. It has been approved in 2014 in Japan to treat pandemic influenza infections and is reported to inhibit broad-spectrum RNA viruses, including ANDV and SNV [13-18]. Both ribavirin and favipiravir are prodrugs, which have to be metabolized for their conversion 
into efficient substrates for RNA incorporation, ribavirin-RTP and favipiravir-RTP [19-22]. Although both drugs are nucleoside analogues, they have been shown to have a distinct mode of action to inhibit influenza viral polymerase. Ribavirin causes GTP depletion, while favipiravir is used as an alternative nucleoside substrate by the viral polymerase, leading to the production of non-infectious viral particles [23].

In this study, we aimed to determine the antiviral efficacy of favipiravir compared to ribavirin and combined both drugs to boost their potency to protect from HTNV infection.

\section{Materials and Methods}

\subsection{Cells and Viruses}

Monkey kidney epithelial (Vero E6-Vero C1008, ATCC CLR 1586) cells were maintained in Biochrom minimum essential media (MEM) with Earle's salts supplemented with $10 \%(v / v)$ FCS, $0.625 \%$ L-glutamine, $0.5 \%$ penicillin-streptomycin and $0.5 \%$ NEAA (Biochrom, Cambridge, UK) at $37^{\circ} \mathrm{C}$. For infection and viability studies, cells were seeded in 48-well plates at 50,000 cells/well and cultured for $16 \mathrm{~h}$ until cell monolayer formation. HTNV strain 76/118 [24] was propagated in Vero E6 cells for 15 days.

\subsection{Inhibitor Treatment on Authentic Pathogenic Viruses, RNA Isolation, and RT-qPCR}

Favipiravir (T-705) was from Toyama Chemical Co., Ltd. (Tokyo, Japan), diluted in DMSO at a concentration stock of $100 \mathrm{mM}$. For infection studies, favipiravir was tested at 5 , 10, 15, $20 \mu \mathrm{M}$. Ribavirin was obtained from Sigma (Buchs, Switzerland), diluted at $10 \mathrm{mM}$ in $\mathrm{H}_{2} \mathrm{O}$ and tested at $6.25,12.5,18.75,25 \mu \mathrm{M}$. Drug interaction was tested in a $5 \times 5$ matrix in all possible combinations.

$100 \%$ confluent cultures of Vero E6 cells were pre-treated with previously mentioned concentrations of favipiravir and/or ribavirin for $1 \mathrm{~h}$. Cells were subsequently infected for $1 \mathrm{~h}$ with HTNV 76/118 strain (MOI of 1) in presence of the drug, washed once with medium, and incubated for 5 days with appropriate drug concentration. $100 \mu \mathrm{L}$ of cell supernatants were collected and inactivated in $800 \mu \mathrm{L}$ AVL-absolute EtOH solution. Viral RNA was isolated using MagNA Pure 96 Instrument (Roche, Mannheim, Germany). Quantification of viral RNA was performed using a real-time quantitative polymerase chain reaction (RT-qPCR) assay, specific for HTNV nucleocapsid coding region. TaqMan ${ }^{\circledR}$ Fast virus 1-Step Master $(4 \times)$, as well as HTNV PMGB1 probe (TCAATGGGGATACAACT) and HTNV primers (forward 5'-CATGGCATCHAAGACAGTKGG-3', reverse 3'- TTWCCCCAGGCAACCAT-5') were obtained from Applied Biosystems ${ }^{\circledR}$ (Waltham, MA, USA). RT-qPCR was conducted in a LigthCycler ${ }^{\circledR} 96$ (Roche), following manufacturer's instructions. For each experiment, one sample per condition was collected and experiments were conducted at least 3 times.

\subsection{Therapeutic Index}

To calculate the therapeutic index (TI), 100\% confluent monolayers of Vero E6 cells were treated with ribavirin or favipiravir starting at $100 \mu \mathrm{M}$ concentration, followed by a $\sim 1.5$-fold serial dilution for 5 days (concentrations tested: $0,1,2.5,5,10,12.5,25 \mu \mathrm{M}$ ). After 5 days, cells were treated with $1 \%$ Triton- 100 (diluted in water) for $15 \mathrm{~min}$ at $37^{\circ} \mathrm{C}$ in order to totally lyse the cells and obtain the background levels. The cytotoxicity of ribavirin and favipiravir was assessed using CellTiter-Glo ${ }^{\circledR}$ Assay System (Promega, Madison, WI, USA), which determines the number of viable cells on the basis of ATP levels, with the TriStar LB 941 (Berthold Technologies, Bad Wildbad, Germany) luminometer. The median toxic dose $\left(\mathrm{TD}_{50}\right)$ was calculated based on the cell viability values, while the median effective dose $\left(\mathrm{ED}_{50}\right)$ on inhibition of HTNV replication by RT-qPCR. Therapeutic index was finally calculated as followed: $\mathrm{TD}_{50} / \mathrm{ED}_{50}$.

\subsection{Data Analysis}

The Bliss synergy analysis was performed using Synergy Finder software (SynergyFinder 2.0: visual analytics of multi-drug combination synergies, Helsinki, Finland [25]). Dose-response curves for ribavirin and favipiravir were generated and $\mathrm{IC}_{90}$ for each in- 
dividual drug were calculated with GraphPad Prism 7 software (San Diego, CA, USA, www.graphpad.com) to perform the combination studies. The $5 \times 5$ matrix was designed around IC $\mathrm{C}_{90}$ values and for each combination, percentage of inhibition was assigned in the dose-response matrix. In the synergy map, score and color are indicating the degree of either antagonism (green, decreased effect, score $>-10$ ), additivity (white, score from -10 to 10 ), or synergism (red, increased effect, score $>10$ ).

\subsection{Statistical Analysis}

Graphical representation and statistical analysis were performed using GraphPad Prism 7 software. Data are means + SD $(n=3)$ and $p$ values of $<0.05$ were considered statistically significant.

\section{Results}

\subsection{Ribavirin and T-705 Demonstrate Similar Antiviral Activity against HTNV Infection}

To assess antiviral drug activity of ribavirin and T-705 against HTNV infection, Vero E6 cells were treated with increasing concentration of both compounds prior to infection. Virus production in the cell supernatant was detected using a highly sensitive real-time quantitative polymerase chain reaction (RT-qPCR) 5 days post-infection.

Ribavirin and favipiravir both inhibited HTNV infection in a dose-dependent manner. The $\mathrm{IC}_{50}$ of ribavirin corresponded to $2.65 \mu \mathrm{M}$ and the $\mathrm{IC}_{90}$ of $10.49 \mu \mathrm{M}$, whereas favipiravir demonstrated an $\mathrm{IC}_{50}$ of $3.89 \mu \mathrm{M}$ and $\mathrm{IC}_{90}$ of $9.79 \mu \mathrm{M}$ (Figure 1A). The drugs applied under the assay conditions demonstrated no cytotoxic effect, as observed by a measurement of the cell viability (Figure 1B). Overall, both compounds inhibit HTNV infection with high potency.

A
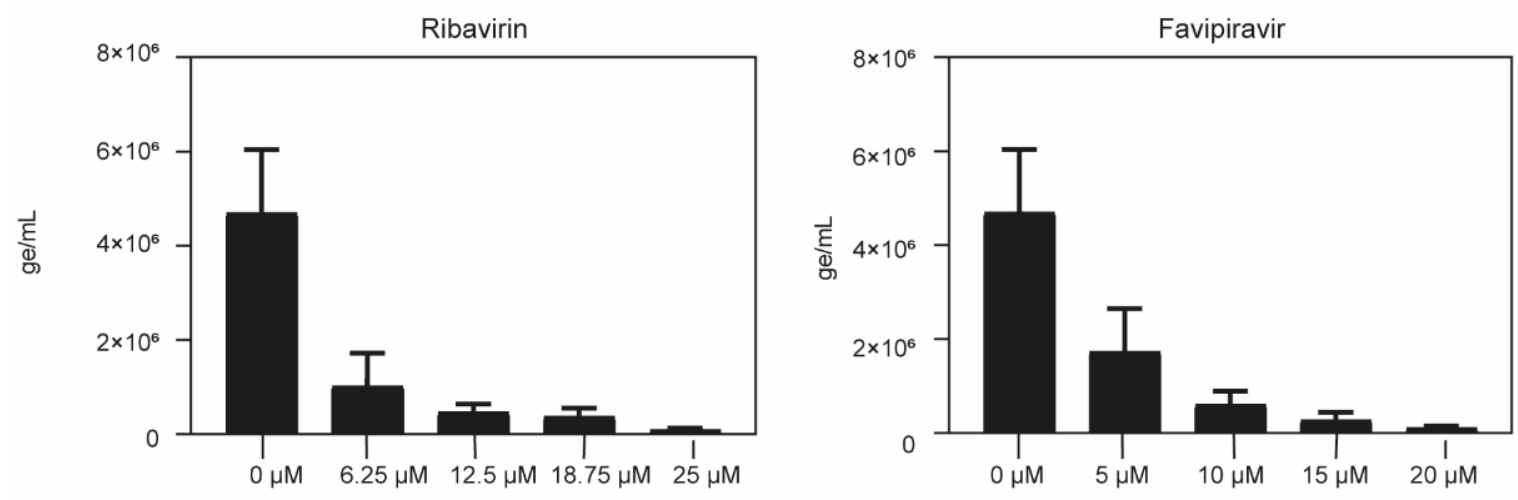

B

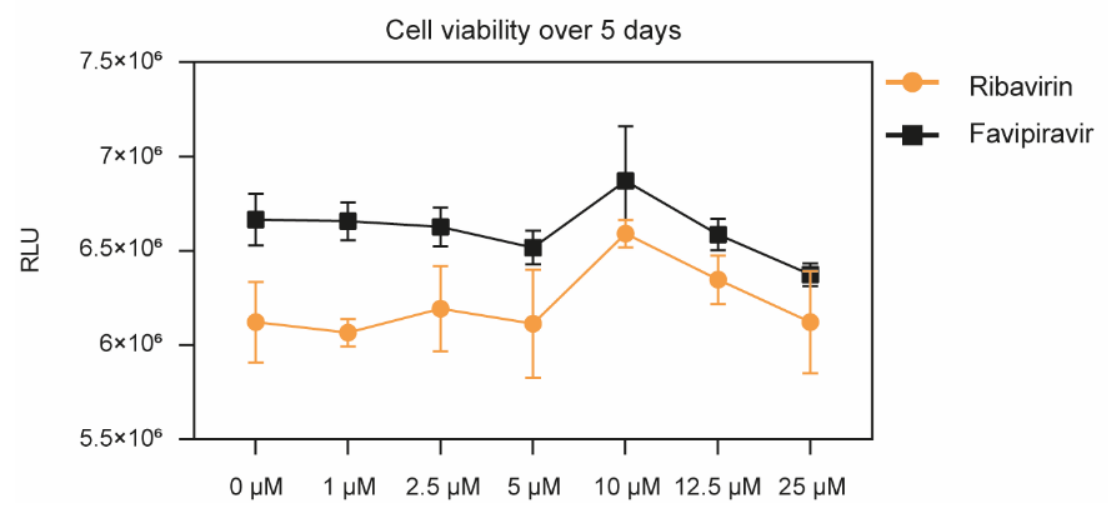

Figure 1. Antiviral activity of ribavirin and favipiravir. (A) Dose-response curve in Vero E6 cells treated with ribavirin, or favipiravir. Vero E6 cells were pre-incubated with ribavirin or favipiravir at the indicated concentrations for $1 \mathrm{~h}$ at $37^{\circ} \mathrm{C}$, followed by Hantaan virus (HTNV) infection for $1 \mathrm{~h}$ at $37^{\circ} \mathrm{C}$. Cells were subsequently washed once with medium and 
incubated with medium containing appropriate drug concentration for 5 days. At 5 dpi, the viral titer on the cell supernatant was determined by RT-qPCR. Data are means + SD $(n=3)$ of genome per mL. (B) Cell viability over 5 days. Monolayers of Vero E6 cells were treated with the indicated concentration of ribavirin and favipiravir under the assay conditions. After 5 days, intracellular ATP levels were measured using CellTiter-Glo ${ }^{\circledR}$ assay. Data are means \pm SD $(n=3)$ of Relative Light Units (RLU) of three independent experiments.

\subsection{Additive Effect between Ribavirin and T-705 in Inhibiting Hantavirus Replication}

As ribavirin is the standard treatment for HFRS disease, and that T-705 is a potent novel antiviral against HTNV infection, we next investigated whether T-705 would result in a synergistic, additive, or antagonistic effect with ribavirin. We designed a $5 \times 5$ concentration matrix around the $\mathrm{IC}_{90}$ values of both drugs (Figure 2A). Vero E6 cells were treated for 60 min with increasing concentration of ribavirin and favipiravir, followed by $1 \mathrm{~h}$ infection with HTNV. Inoculum was then removed, and medium with appropriate drug concentration was added for 5 days. Virus production in the cell supernatant was determined by RT-qPCR.

A

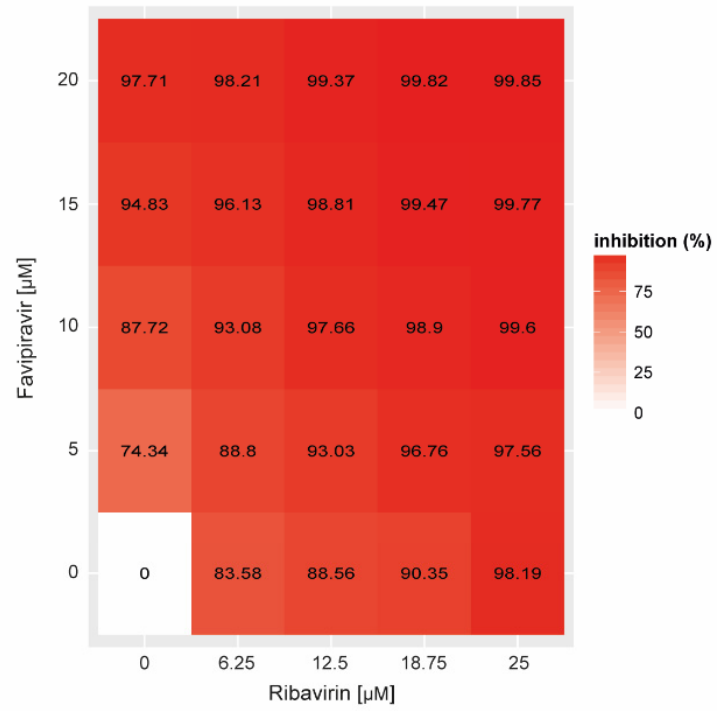

C

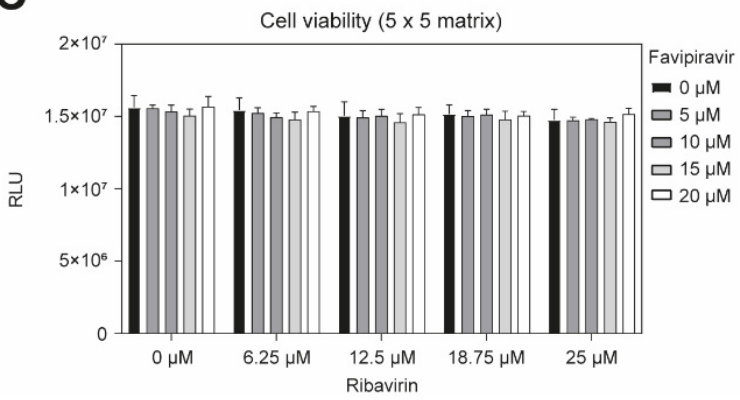

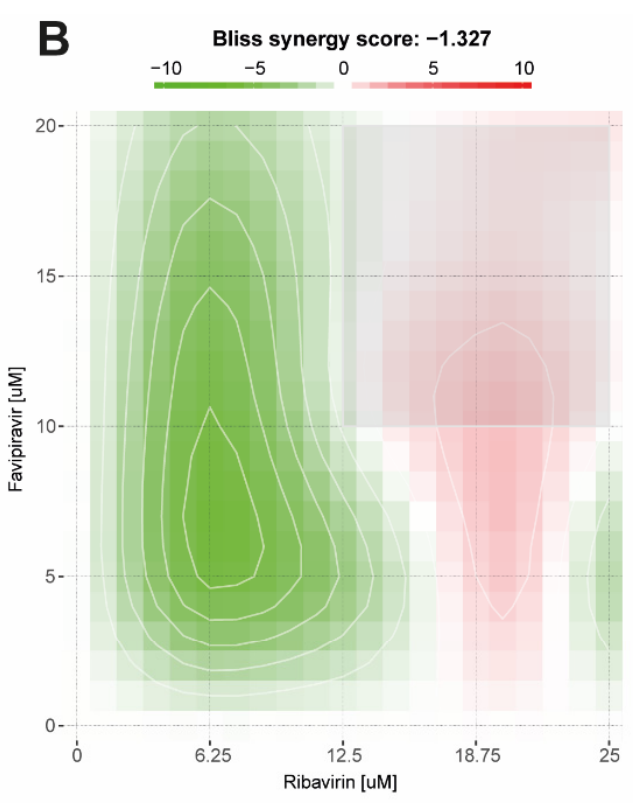

$-2$ 
To evaluate antagonistic or synergistic effects, we used the Bliss independence model, which states that two drugs have an independent effect, and their combination is calculated based on the probability of independent events [26-28]. As ribavirin and favipiravir have been demonstrated to block infection via distinct modes of action, they are considered to act independently [23]. All combinations demonstrated a strong antiviral efficacy (Figure 2B), and the drug combinations demonstrated no cell toxicity (Figure 2C). The highest antiviral activity showing a decrease of HTNV particles from $5.8 \times 10^{6}$ to $6.3 \times 10^{4}$ genome $/ \mathrm{mL}$ and corresponding to $>99 \%$ of inhibition, is observed with the drug combination $12 \mu \mathrm{M}$ favipiravir $/ 18.75 \mu \mathrm{M}$ ribavirin. The Bliss synergy score of -1.327 argues for an additive effect.

We then calculated the toxicity index (TI) to determine the relative safety of the drugs ribavirin and favipiravir (Table 1). Vero E6 cells were treated under the assay conditions from 1 to $100 \mu \mathrm{M}$. 5 days post-treatment, cells were lysed with $1 \%$ Triton-100 to obtain the background values. Ribavirin is the compound demonstrating the highest relative safety with a therapeutic index of $4.9 \times 10^{5}: 1$, while favipiravir has a lower therapeutic index of $4.3 \times 10^{3}: 1$.

Table 1. Therapeutic index. The therapeutic index (TI) is defined as toxic dose $\left(\mathrm{TD}_{50}\right) /$ effective dose $\left(\mathrm{EC}_{50}\right)$.

\begin{tabular}{cccc}
\hline & Toxic Dose $\left(\right.$ TD $\left._{50}\right)$ & Effective Dose $\left(\right.$ ED $\left._{50}\right)$ & Therapeutic Index $($ TI) \\
\hline Ribavirin & $1,306,801 \mu \mathrm{M}$ & $2.647 \mu \mathrm{M}$ & $4.9 \times 10^{5}$ \\
Favipiravir (T-705) & $16,796 \mu \mathrm{M}$ & $3.888 \mu \mathrm{M}$ & $4.3 \times 10^{3}$ \\
\hline
\end{tabular}

\section{Discussion}

Hantaan virus (HTNV) is responsible of HFRS, a severe human disease and the therapeutic approaches currently used are limited to supportive care, highlighting the need for novel therapeutic strategies against pathogenic HTNV.

The antiviral used currently, ribavirin, improves HFRS disease outcome when given early in infection, while its effectiveness to treat HCPS is less clear [29,30]. Moreover, ribavirin is associated with some side effects, including hemolytic anemia, and cannot be applied in pregnant women. Another more recently approved antiviral molecule, demonstrating broad-spectrum antiviral activity on RNA viruses, is favipiravir (T-705) [16]. This compound has been approved for influenza treatment in Japan since 2014 [31] and was administered during the West Africa Ebola outbreak as an emergency antiviral strategy [32,33]. Favipiravir was previously shown to have an inhibitory effect on RNA viruses, among them the arenaviruses Lassa (LASV) and Junín, as well as SNV and ANDV, in vitro and in vivo [13,18,34-37]. Favipiravir could thus represent a potent antiviral to treat HFRS. In this study, we first aimed to evaluate and compare the antiviral effect of favipiravir and ribavirin. Both drugs show high potency and similarly inhibit HTNV infection with an $\mathrm{IC}_{50}$ around $3 \mu \mathrm{M}$ and an $\mathrm{IC}_{90}$ around $10 \mu \mathrm{M}$. However, as favipiravir was demonstrated to have higher antiviral activity in vivo for several viruses, including CrimeanCongo hemorrhagic fever, Lassa, and Ebola viruses [27,37,38], we may consider T-705 as a stand-alone treatment.

Regarding the biochemical mechanism, ribavirin and favipiravir have been shown to have distinct modes of action to inhibit influenza viral polymerase [23]. As both drugs block infection via different mechanisms, we tested the impact of the combination of the two drugs on HTNV infection. The drug concentrations used in these experiments were selected based on the $\mathrm{IC}_{90}$ values, as previously determined for LASV infection in animal models to observe an effective antiviral activity [26]. Our results indicate that ribavirin and favipiravir have an additive interaction when suboptimal doses were combined compared to treatment with each drug alone. These in vitro data suggest that favipiravir could decrease the ribavirin concentration needed in vivo, and consequently lower the associated side effects. One limitation in using ribavirin or favipiravir as monotherapy is the virulence and high mutation rates of human pathogenic RNA viruses [38,39], which can lead to the 
emergence of viral resistance and thus decrease antiviral activity, as illustrated by HIV [40]. Therefore, the combination of antiviral treatment is a promising strategy.

The precise mode of action of both drugs on HTNV infection are yet to be elucidated. In analogy to other RNA viruses, one may speculate that ribavirin lowers GTP levels, increasing the use of the nucleoside analogue T-705, which in turn is incorporated into RNA strands to induce viral mutagenesis. The mechanism of favipiravir on HTNV still requires further investigation. It has been previously shown that ribavirin induces mutation into the viral genome of HTNV, leading to errors in viral replication and thus the production of non-infectious viral particles [41]. Although RT-qPCR allows a precise quantification of viral RNA, it remains to be determined whether the newly synthesized virion are infectious. In a follow-up study, we plan to count the number of infectious particles using focus assays, and perform a deeper analysis using high throughput sequencing in order to determine the type and frequency of the mutations after drug treatment [41]. These studies may allow us to better understand the different mechanisms of action of ribavirin and favipiravir in the context of HTNV infection.

Although further experiments are required to investigate the toxicity and the in vivo antiviral potency, the lack of an appropriate animal model exhibiting clinical signs of the HFRS disease renders this difficult [42]. On the other hand, Syrian hamsters are useful animal models for HCPS and recapitulate the clinical human disease [43-46]. A previous in vivo study on LASV demonstrated the potential of combined drug treatment to significantly increase the survival rate in mice [26]. Most interestingly, two human patients infected with LASV were successfully treated with a combination of ribavirin/favipiravir [47]. These studies open a new avenue of research and indicate that a combination of ribavirin/favipiravir could constitute a potential treatment of the diseases caused by HTNV and others. The risk of resistance triggered by the use of a single replication inhibitor has to be considered. A promising line of approach is therefore the combination of antiviral drugs that target different steps of the viral lifecycle. Attacking the virus from different angles make it less likely for drug-resistance to occur. Several molecules inhibiting HTNV entry were identified in our laboratory, but their uses still need further investigation in combinatory studies with replication inhibitors [48-50].

In the context of sporadic outbreaks caused by hantaviruses, as well as imported cases of infected patients, the diagnosis and clinical management remains a challenge. In Switzerland, two imported cases of ANDV infection and three of PUUV infection were recently reported [51,52]. Regarding HCPS cases, the two patients were a 55-year-old man and his 54-year-old wife returning from South America. The husband first developed fever on the day of their return to Switzerland, while he deteriorated and required non-invasive ventilator support, ANDV infection had been confirmed by RT-qPCR 8 days later. At this time point, his wife demonstrated no clinical symptoms, and the serology and RT-qPCR tests were negative. However, 28 days after her husband's first symptoms, she also presented to the hospital with pronounced weakness, myalgia, and shortness of breath. On the second day, she was diagnosed positive for ANDV infection and remained 5 months in the intensive care unit, followed by pulmonary intermediate care for 1 month and another complete year in neuro-pulmonary rehabilitation. In contrast, after influenza-like symptoms of the mother and fatal PUUV infection of the father (45 years of age), the patients' daughter received a successful 5-day course of oral ribavirin. A prophylactic treatment therefore represents a helpful protection for the other family members. In vitro studies demonstrating antiviral efficacy therefore lay the basis for considering an experimental therapy.

Early diagnosis, allowing rapid therapeutic intervention, will significantly improve the outcome of hantavirus disease. Lowering the viral load early in infection will provide the patient's immune system precious time to mount an antiviral response that will control and ultimately clear infection. We expect that treatment with ribavirin and favipiravir for post-exposure prophylaxis and during early infection may reduce mortality and provide better treatment than is currently available. 
Author Contributions: Conceptualization, J.M., O.E. and S.R.; methodology, J.M. and S.R.; validation, J.M. and S.R.; formal analysis, J.M. and S.R.; investigation, J.M. and S.R.; resources, S.R. and O.E.; data curation, J.M. and S.R.; writing-original draft preparation, J.M., O.E. and S.R.; writing-revision, J.M. and S.R.; supervision, S.R.; project administration, S.R. and O.E.; funding acquisition, S.R. and O.E. All authors have read and agreed to the published version of the manuscript.

Funding: This research was supported by Swiss Federal Office for Civil protection (Vertrag 353008564/STM, Vertrag 353008560/STM). J.M. was supported by funds from the University of Lausanne to Stefan Kunz.

Institutional Review Board Statement: Not applicable.

Informed Consent Statement: Not applicable.

Data Availability Statement: All data are available under request.

Acknowledgments: We thank the virology team at Spiez Laboratory for helping to establish the Hantaan virus culture and validation experiment.

Conflicts of Interest: The authors declare no conflict of interest.

\section{References}

1. Jonsson, C.B.; Figueiredo, L.T.M.; Vapalahti, O. A Global Perspective on Hantavirus Ecology, Epidemiology, and Disease. Clin. Microbiol. Rev. 2010, 23, 412-441. [CrossRef]

2. Vaheri, A.; Henttonen, H.; Voutilainen, L.; Mustonen, J.; Sironen, T.; Vapalahti, O. Hantavirus infections in Europe and their impact on public health. Rev. Med. Virol. 2013, 23, 35-49. [CrossRef] [PubMed]

3. Vaheri, A.; Strandin, T.; Hepojoki, J.; Sironen, T.; Henttonen, H.; Mäkelä, S.; Mustonen, J. Uncovering the mysteries of hantavirus infections. Nat. Rev. Microb. 2013, 11, 539-550. [CrossRef] [PubMed]

4. Martinez, V.P.; Bellomo, C.; Juan, J.S.; Pinna, D.; Forlenza, R.; Elder, M.; Padula, P.J. Person-to-Person Transmission of Andes Virus. Emerg. Infect. Dis. 2005, 11, 1848-1853. [CrossRef]

5. Martínez, V.P.; Di Paola, N.; Alonso, D.O.; Pérez-Sautu, U.; Bellomo, C.M.; Iglesias, A.A.; Coelho, R.M.; López, B.; Periolo, N.; Larson, P.A.; et al. "Super-Spreaders" and Person-to-Person Transmission of Andes Virus in Argentina. N. Engl. J. Med. 2020, 383, 2230-2241. [CrossRef] [PubMed]

6. Padula, P.J.; Miguel, S.D.L.; Lopez, N.M.; Rossi, C.M.; Rabinovich, R.D. Hantavirus Pulmonary Syndrome Outbreak in Argentina: Molecular Evidence for Person-to-Person Transmission of Andes V. Virology 1998, 241, 323-330. [CrossRef] [PubMed]

7. Wells, R.M.; Yadon, E.Z.; Enria, D.; Padula, P.; Pini, N.; Mills, J.N.; Peters, C.J.; Segura, E.L. Hantavirus Pulmonary Syndrome Study Group for Patagonia An Unusual Hantavirus Outbreak in Southern Argentina Person-to-Person Transmission. Emerg. Infect. Dis. 1997, 3, 171-174. [CrossRef] [PubMed]

8. Brocato, R.L.; Hooper, J.W. Progress on the Prevention and Treatment of Hantavirus Disease. Viruses 2019, 11, 610. [CrossRef]

9. Iannetta, M.; Di Caro, A.; Nicastri, E.; Vairo, F.; Masanja, H.; Kobinger, G.; Mirazimi, A.; Ntoumi, F.; Zumla, A.; Ippolito, G. Viral Hemorrhagic Fevers Other than Ebola and Lassa. Infect. Dis. Clin. N. Am. 2019, 33, 977-1002. [CrossRef]

10. Huggins, J.W. Prospective, Double-Blind, Concurrent, Placebo-Controlled Clinical Trial of Intravenous Ribavirin Therapy ofHemorrhagic Fever with Renal Syndrome. J. Infect. Dis. 1991, 164, 1119-1127. [CrossRef]

11. Rusnak, J.M.; Byrne, W.R.; Chung, K.N.; Gibbs, P.H.; Kim, T.T.; Boudreau, E.F.; Cosgriff, T.; Pittman, P.; Kim, K.Y.; Erlichman, M.S.; et al. Experience with intravenous ribavirin in the treatment of hemorrhagic fever with renal syndrome in Korea. Antivir. Res. 2009, 81, 68-76. [CrossRef]

12. Fernandez, G.B.H.; Smith, R. Ribavirin: A Clinical Overview. Eur. J. Epidemiol. 1986, 2, 1-14. [CrossRef] [PubMed]

13. Safronetz, D.; Haddock, E.; Feldmann, F.; Ebihara, H.; Feldmann, H. In Vitro and In Vivo Activity of Ribavirin against Andes Virus Infection. PLoS ONE 2011, 6, e23560. [CrossRef]

14. Furuta, Y.; Takahashi, K.; Fukuda, Y.; Kuno, M.; Kamiyama, T.; Kozaki, K.; Nomura, N.; Egawa, H.; Minami, S.; Watanabe, Y.; et al. In Vitro and In Vivo Activities of Anti-Influenza Virus Compound T-705. Antimicrob. Agents Chemother. 2002, 46, 977-981. [CrossRef]

15. Gowen, B.B.; Wong, M.-H.; Jung, K.-H.; Sanders, A.B.; Mendenhall, M.; Bailey, K.W.; Furuta, Y.; Sidwell, R.W. In Vitro and In Vivo Activities of T-705 against Arenavirus and Bunyavirus Infections. Antimicrob. Agents Chemother. 2007, 51, 3168-3176. [CrossRef] [PubMed]

16. Furuta, Y.; Takahashi, K.; Shiraki, K.; Sakamoto, K.; Smee, D.F.; Barnard, D.L.; Gowen, B.B.; Julander, J.G.; Morrey, J.D. T-705 (favipiravir) and related compounds: Novel broad-spectrum inhibitors of RNA viral infections. Antivir. Res. 2009, 82, 95-102. [CrossRef] [PubMed]

17. Shiraki, K.; Daikoku, T. Favipiravir, an anti-influenza drug against life-threatening RNA virus infections. Pharmacol. Ther. 2020, 209, 107512. [CrossRef]

18. Gowen, B.B.; Westover, J.B.; Sefing, E.J.; Van Wettere, A.J.; Bailey, K.W.; Wandersee, L.; Komeno, T.; Furuta, Y. Enhanced protection against experimental Junin virus infection through the use of a modified favipiravir loading dose strategy. Antivir. Res. 2017, 145, 131-135. [CrossRef] 
19. Furuta, Y.; Takahashi, K.; Kuno-Maekawa, M.; Sangawa, H.; Uehara, S.; Kozaki, K.; Nomura, N.; Egawa, H.; Shiraki, K. Mechanism of Action of T-705 against Influenza Virus. Antimicrob. Agents Chemother. 2005, 49, 981-986. [CrossRef]

20. Naesens, L.; Guddat, L.; Keough, D.T.; Van Kuilenburg, A.B.P.; Meijer, J.; Voorde, J.V.; Balzarini, J. Role of Human Hypoxanthine Guanine Phosphoribosyltransferase in Activation of the Antiviral Agent T-705 (Favipiravir). Mol. Pharmacol. $2013,84,615-629$. [CrossRef]

21. Parker, W.B. Metabolism and antiviral activity of ribavirin. Virus Res. 2005, 107, 165-171. [CrossRef] [PubMed]

22. Gallois-Montbrun, S.; Chen, Y.; Dutartre, H.; Sophys, M.; Morera, S.; Guerreiro, C.; Schneider, B.; Mulard, L.; Janin, J.; Veron, M.; et al. Structural analysis of the activation of ribavirin analogs by NDP kinase: Comparison with other ribavirin targets. Mol. Pharmacol. 2003, 63, 538-546. [CrossRef] [PubMed]

23. Vanderlinden, E.; Vrancken, B.; Van Houdt, J.; Rajwanshi, V.K.; Gillemot, S.; Andrei, G.; Lemey, P.; Naesens, L. Distinct Effects of T-705 (Favipiravir) and Ribavirin on Influenza Virus Replication and Viral RNA Synthesis. Antimicrob. Agents Chemother. 2016, 60, 6679-6691. [CrossRef]

24. Lee, H.W.; Lee, P.W.; Johnson, K.M. Isolation of the Etiologic Agent of Korean Hemorrhagic Fever. J. Infect. Dis. 1978, 137, $298-308$. [CrossRef]

25. Ianevski, A.; Giri, A.K.; Aittokallio, T. SynergyFinder 2.0: Visual analytics of multi-drug combination synergies. Nucleic Acids Res. 2020, 48, W488-W493. [CrossRef] [PubMed]

26. Oestereich, L.; Rieger, T.; Lüdtke, A.; Ruibal, P.; Wurr, S.; Pallasch, E.; Bockholt, S.; Krasemann, S.; Muñoz-Fontela, C.; Günther, S. Efficacy of Favipiravir Alone and in Combination with Ribavirin in a Lethal, Immunocompetent Mouse Model of Lassa Fever. J. Infect. Dis. 2016, 213, 934-938. [CrossRef]

27. Welch, S.R.; Scholte, F.; Flint, M.; Chatterjee, P.; Nichol, S.T.; Bergeron, É.; Spiropoulou, C.F. Identification of 2'-deoxy-2'fluorocytidine as a potent inhibitor of Crimean-Congo hemorrhagic fever virus replication using a recombinant fluorescent reporter virus. Antivir. Res. 2017, 147, 91-99. [CrossRef]

28. Herring, J.M.O.; Wagoner, J.; Kirchmeier, D.; O'Connor, A.; Nelson, E.A.; Huang, L.E.D.; Liang, Y.; Johansen, L.M.; Glass, P.J.; Olinger, G.G.; et al. Inhibition of Arenaviruses by Combinations of Orally Available Approved Drugs. Antimicrob. Agents Chemother. 2021, 65, e01146-20.

29. Chapman, L.E.; Ellis, B.A.; Koster, F.T.; Sotir, M.; Ksiazek, T.G.; Mertz, G.J.; Rollin, P.E.; Baum, K.F.; Pavia, A.T.; Christenson, J.C.; et al. Discriminators between Hantavirus-Infected and -Uninfected Persons Enrolled in a Trial of Intravenous Ribavirin for Presumptive Hantavirus Pulmonary Syndrome. Clin. Infect. Dis. 2002, 34, 293-304. [CrossRef]

30. Mertz, G.J.; Hjelle, B.; Crowley, M.; Iwamoto, G.; Tomicic, V.; Vial, P.A. Diagnosis and treatment of new world hantavirus infections. Curr. Opin. Infect. Dis. 2006, 19, 437-442. [CrossRef]

31. Furuta, Y.; Gowen, B.B.; Takahashi, K.; Shiraki, K.; Smee, D.F.; Barnard, D.L. Favipiravir (T-705), a novel viral RNA polymerase inhibitor. Antivir. Res. 2013, 100, 446-454. [CrossRef]

32. Guedj, J.; Piorkowski, G.; Jacquot, F.; Madelain, V.; Nguyen, T.H.T.; Rodallec, A.; Gunther, S.; Carbonnelle, C.; Mentré, F.; Raoul, H.; et al. Antiviral efficacy of favipiravir against Ebola virus: A translational study in cynomolgus macaques. PLoS Med. 2018, 15, e1002535. [CrossRef]

33. Foucquier, J.; Guedj, M. Analysis of drug combinations: Current methodological landscape. Pharmacol. Res. Perspect. 2015, 3, e00149. [CrossRef]

34. Safronetz, D.; Falzarano, D.; Scott, D.P.; Furuta, Y.; Feldmann, H.; Gowen, B.B. Antiviral Efficacy of Favipiravir against Two Prominent Etiological Agents of Hantavirus Pulmonary Syndrome. Antimicrob. Agents Chemother. 2013, 57, 4673-4680. [CrossRef] [PubMed]

35. Buys, K.K.; Jung, K.-H.; Smee, D.F.; Furuta, Y.; Gowen, B.B. Maporal Virus as a Surrogate for Pathogenic New World Hantaviruses and its Inhibition by Favipiravir. Antivir. Chem. Chemother. 2011, 21, 193-200. [CrossRef] [PubMed]

36. Rosenke, K.; Feldmann, H.; Westover, J.B.; Hanley, P.W.; Martellaro, C.; Feldmann, F.; Saturday, G.; Lovaglio, J.; Scott, D.P.; Furuta, Y.; et al. Use of Favipiravir to Treat Lassa Virus Infection in Macaques. Emerg. Infect. Dis. 2018, 24, 1696-1699. [CrossRef] [PubMed]

37. Delang, L.; Abdelnabi, R.; Neyts, J. Favipiravir as a potential countermeasure against neglected and emerging RNA viruses. Antivir. Res. 2018, 153, 85-94. [CrossRef]

38. Duffy, S.; Shackelton, L.A.; Holmes, E.C. Rates of evolutionary change in viruses: Patterns and determinants. Nat. Rev. Genet. 2008, 9, 267-276. [CrossRef]

39. Sanjuan, R. Viral mutation rates. J. Virol. 2010, 84, 9733-9748. [CrossRef] [PubMed]

40. Giacomelli, A.; Pezzati, L.; Rusconi, S. The crosstalk between antiretrovirals pharmacology and HIV drug resistance. Expert Rev. Clin. Pharmacol. 2020, 13, 739-760. [CrossRef] [PubMed]

41. Chung, D.-H.; Sun, Y.; Parker, W.B.; Arterburn, J.B.; Bartolucci, A.; Jonsson, C.B. Ribavirin Reveals a Lethal Threshold of Allowable Mutation Frequency for Hantaan Virus. J. Virol. 2007, 81, 11722-11729. [CrossRef]

42. Perley, C.C.; Brocato, R.L.; Kwilas, S.A.; Daye, S.; Moreau, A.; Nichols, D.K.; Wetzel, K.S.; Shamblin, J.; Hooper, J.W. Three asymptomatic animal infection models of hemorrhagic fever with renal syndrome caused by hantaviruses. PLoS ONE 2019, 14, e0216700. [CrossRef] [PubMed] 
43. Brocato, R.L.; Hammerbeck, C.D.; Bell, T.M.; Wells, J.B.; Queen, L.A.; Hooper, J.W. A Lethal Disease Model for Hantavirus Pulmonary Syndrome in Immunosuppressed Syrian Hamsters Infected with Sin Nombre Virus. J. Virol. 2014, 88, 811-819. [CrossRef] [PubMed]

44. Hooper, J.; Larsen, T.; Custer, D.; Schmaljohn, C. A Lethal Disease Model for Hantavirus Pulmonary Syndrome. Virology 2001, 289, 6-14. [CrossRef] [PubMed]

45. Safronetz, D.; Ebihara, H.; Feldmann, H.; Hooper, J.W. The Syrian hamster model of hantavirus pulmonary syndrome. Antivir. Res. 2012, 95, 282-292. [CrossRef] [PubMed]

46. Golden, J.W. Animal Models for the Study of Rodent-Borne Hemorrhagic Fever Viruses: Arenaviruses and Hantaviruses. BioMed Res. Int. 2015, 2015, 793257. [CrossRef] [PubMed]

47. Raabe, V.; Kann, G.; Ribner, B.S.; Morales, A.; Varkey, J.B.; Mehta, A.K.; Lyon, G.M.; Vanairsdale, S.; Faber, K.; Becker, S.; et al. Favipiravir and Ribavirin Treatment of Epidemiologically Linked Cases of Lassa Fever. Clin. Infect. Dis. 2017, 65, 855-859. [CrossRef] [PubMed]

48. Torriani, G.; Mayor, J.; Zimmer, G.; Kunz, S.; Rothenberger, S.; Engler, O. Macropinocytosis contributes to hantavirus entry into human airway epithelial cells. Virology 2019, 531, 57-68. [CrossRef]

49. Mayor, J.; Torriani, G.; Rothenberger, S.; Engler, O. T-cell immunoglobulin and mucin (TIM) contributes to the infection of human airway epithelial cells by pseudotype viruses containing Hantaan virus glycoproteins. Virology 2020, 543, 54-62. [CrossRef] [PubMed]

50. Mayor, J.; Torriani, G.; Engler, O.; Rothenberger, S. Identification of Novel Antiviral Compounds Targeting Entry of Hantaviruses. Viruses 2021, 13, 685. [CrossRef]

51. Vetter, P.; L'Huillier, A.G.; Montalbano, M.F.; Pigny, F.; Eckerle, I.; Torriani, G.; Rothenberger, S.; Laubscher, F.; Cordey, S.; Kaiser, L.; et al. Puumala Virus Infection in Family, Switzerland. Emerg. Infect. Dis. 2021, 27, 658-660. [CrossRef] [PubMed]

52. Kuenzli, A.B.; Marschall, J.; Schefold, J.C.; Schafer, M.; Engler, O.B.; Ackermann-Gäumann, R.; Reineke, D.C.; Suter-Riniker, F.; Staehelin, C. Hantavirus Cardiopulmonary Syndrome Due to Imported Andes Hantavirus Infection in Switzerland: A Multidisciplinary Challenge, Two Cases and a Literature Review. Clin. Infect. Dis. 2018, 67, 1788-1795. [CrossRef] [PubMed] 